NBER WORKING PAPER SERIES

\author{
DO REPATRIATION TAXES MATTER? \\ EVIDENCE FROM THE TAX RETURNS \\ OF U.S. MULTINATIONALS
}

\author{
Rosanne Altshuler \\ T. Scott Newion \\ William C. Randolph
}

Working Paper No. 4667
NATIONAL BUREAU OF ECONOMIC RESEARCH
1050 Massachusetts Avenue
Cambridge, MA 02138
March 1994

\begin{abstract}
Prepared for the 1994 NBER Conference on International Taxation. We are very grateful to Gordon Wilson for his assistance in using the Treasury tax data. We thank Bill Gentry and other conference participants for valuable comments. We also thank seminar participants at the University of Pennsylvania, the University of Toronto, and the 1993 NBER Summer Institute for helpful comments. Any views expressed in this paper are those of the authors and do not necessarily represent those of the U.S. Treasury Department or the National Bureau of Economic Research. This paper is part of NBER's research program in Public Economics.
\end{abstract}


NBER Working Paper \#4667

March 1994

\title{
DO REPATRIATION TAXES MATTER? \\ EVIDENCE FROM THE TAX RETURNS \\ OF U.S. MULTINATIONALS
}

\begin{abstract}
An open question in the literature on the taxation of multinational corporations is whether repatriation taxes influence whether the profits of foreign subsidiaries are repatriated or reinvested abroad. Theoretical models suggest that dividend remittances should not be influenced by repatriation taxes. The results of recent empirical work indicate that dividend remittances are sensitive to repatriation taxes. This paper investigates whether the empirical evidence can be reconciled with the theoretical results by recognizing that repatriation taxes on dividends may vary over time and provide firms with an incentive to time repatriations so that they occur in years when repatriation tax rates are relatively low. We use information about cross-country differences in tax rates to separately estimate the influence of permanent tax changes, as would occur due to changes in statutory tax rates, and transitory tax changes on dividend repatriations. Our data contains U.S. tax return information for a large sample of U.S. corporations and their foreign subsidiaries. We find that the permanent tax price effect is significantly different from the transitory price effect and is not significantly different from zero, while the transitory tax price effect is negative and significant. This suggests that repatriation taxes do affect dividend repatriation behavior but only to the extent that they vary over time. Previous empirical work has apparently measured the effect of timing behavior.

Rosanne Altshuler

Department of Economics

Rutgers University

New Jersey Hall

New Brunswick, NJ 08903

and NBER

William C. Randolph

U.S. Department of Treasury

Office of Tax Analysis

Main Treasury Building

1500 Pennsylvania Avenue, NW

Washington, D.C. 20220

T. Scott Newlon

U.S. Department of Treasury

Office of Tax Analysis

Main Treasury Building

1500 Pennsylvania Avenue, NW

Washington, D.C. 20220
\end{abstract}


An open question in the literature on the taxation of multinational corporations is whether taxes due on repatriation of foreign source income influence whether the profits of foreign subsidiaries are repatriated or reinvested abroad. Theoretical arguments by Hartman (1985) suggest that dividend payments by foreign subsidiaries should not be influenced by such repatriation taxes. Under this view, which is analogous to the "new view" of dividend taxation applied to domestic firms, taxes due upon repatriation are unavoidable costs for "mature" foreign subsidiaries that finance investment out of retained earnings.' As a result, investment and dividend payment decisions are unaffected by those taxes. The results of recent empirical work that used cross-sectional data on U.S. multinationals seem to contradict Hartman's theoretical result. These studies indicate that dividend remittances are sensitive to repatriation taxes. This presents a puzzle.

Hartman's analysis (and the "new view" of dividend taxation) is based on the assumption that taxes on dividends are constant over time. This paper investigates whether the empirical evidence can be reconciled with the theoretical results by recognizing that repatriation taxes on dividends may vary over time. This variability may provide firms with an incentive to repatriate relatively more profits from a subsidiary when the tax cost of doing so is temporarily relatively lower than normal, and to retain more profits when the tax cost of repatriation is higher than normal. ${ }^{2}$ Such timing behavior could be revealed in cross-sectional data by a relationship between dividend payout levels and the current level of the tax cost of dividend payments, when the actual relationship is between dividend payout levels and the current level of the tax cost relative to its normal level. If timing opportunities are important to dividend payout decisions, then it becomes difficult to interpret the tax effects estimated in previous papers. In particular, 
these estimates will tend to confuse the effects of permanent tax changes, as would occur due to changes in statutory tax rates, with the effects of tax changes due to transitory changes in the situation of the taxpayer.

It is important to distinguish whether cross-sectional differences between subsidiaries in dividend payout behavior are due to the current level of the tax cost of paying dividends or the difference between the current and the normal, or expected future, tax cost. Making this distinction will help us evaluate the effects of tax policy on the location of investment, the form of finance, and tax revenues. More specifically, it has implications for the evaluation of policies such as the reduction of withholding tax rates in bilateral tax treaties and the repeal of the deferred taxation that foreign profits generally enjoy in the United States. The policy implications of this work are discussed in more detail in the final section of the paper.

Micro data can be used to distinguish the effects of transitory variation in tax costs from the effects of permanent differences in tax costs. This paper uses a recently created data set containing U.S. tax return information for a large sample of U.S. corporations and their foreign subsidiaries. For some of our empirical work, we link the subsidiary-specific data across time to create a panel data set. To our knowledge, this is the largest panel data set in existence.that contains tax information on multinationals. It is also the only panel data set that has detailed tax information on both the parent corporations and their foreign subsidiaries. 
We use information about cross-country differences in tax rates to estimate separate effects for the permanent and transitory components of the tax price of dividend repatriation. The idea is that variations across countries in average repatriation tax prices or in statutory tax rates will be correlated with the permanent component of tax price variation, but uncorrelated with transitory variations. Using these measures to construct instrumental variables for the tax price allows us to separately identify permanent and transitory tax price effects. Our estimation strategy is similar to that of Burman and Randolph (1993), who used state tax rates as instruments to separate permanent from transitory effects of taxes on capital gains realizations.

To preview our results, we find that the permanent tax price effect is significantly different from the transitory price effect and is not significantly different from zero, while the transitory tax price effect is negative and significant. This suggests that previous cross-sectional analysis has measured the effect of timing behavior, either through tax planning that affects both the tax price and dividend payments or through companies timing their repatriations to take advantage of exogenous transitory variations in tax prices.

The remainder of the paper is organized as follows. Section I briefly reviews Hartman's analysis, the related empirical literature, and some more recent theoretical work in this area. Section II derives the tax price of a dividend repatriation, Section III presents the empirical model, and Section IV describes the data. Results are presented in Section V, followed by concluding remarks. 


\section{The Hartman Analysis and Subsequent Studies}

The United States system for taxing the income earned by the foreign subsidiaries of U.S. corporations defers taxation of foreign income until it is brought back to the United States and provides a credit for foreign taxes paid. ${ }^{3}$ Under this credit and deferral system, the two main forms of repatriation tax that a firm incurs on income remitted from a foreign subsidiary are the residual home country tax liability (if any) not offset by the foreign tax credit, and any withholding tax imposed by the source country. Hartman (1985) argued that, under a credit and deferral tax system, the repatriation tax on foreign source income is irrelevant to the investment and dividend payment decisions of foreign subsidiaries that are financed through retained eamings ("mature" subsidiaries). Hartman's insight was that, since the repatriation tax is unavoidable, it reduces the opportunity cost of investment and the return to investment by the same amount. As a result, the tax does not affect a mature subsidiary's choice between reinvesting its foreign eamings and repatriating funds to its parent." His analysis is essentially an application of the "new view" or "tax capitalization view" of dividend taxation put forward by King (1977), Auerbach (1979), and Bradford (1981). The "new view" holds that taxes on dividends (if constant over time) have no distortionary effects on the real decisions of domestic corporations. Although Hartman's analysis pertains to the residual U.S. tax on foreign income, it applies equally well to withholding taxes.

Several empirical studies using cross-sections of tax return data appear to contradict Hartman's theoretical result. Mutti (1981) used U.S. tax return data from 1972 to estimate the effect of tax costs on the choice of income remittance channels. He found significant tax effects 
in estimates of the parameters of a dividend equation. Goodspeed and Frisch (1989) and Hines and Hubbard (1990) both used 1984 tax return data of large samples of U.S. corporations and their foreign subsidiaries to investigate tax effects on foreign income remittances. Goodspeed and Frisch matched data on parent corporations with country-specific information on their foreign subsidiaries in an attempt to quantify income repatriation incentives created by the U.S. tax system. By further disaggregating the 1984 tax return data, Hines and Hubbard were able to study income repatriation behavior using a data set that matched subsidiary-specific information to parent corporation data. Both studies found significant evidence of tax effects on income repatriation. Altshuler and Newlon (1993) used U.S. tax return data from 1986 to investigate tax effects on dividend remittances from foreign subsidiaries to their U.S. parent corporations. This paper improved upon previous work by providing a more accurate specification of the tax incentives facing firms. Results from estimates of dividend equations indicated a somewhat larger and more significant tax effect than had been previousiy estimated.

Recognizing that Hartman's theoretical analysis did not allow repatriation taxes to vary over time may help to reconcile it with the empirical results from the above studies. There are at least two different ways in which the repatriation tax may vary. First, it may vary over time due to differences between the tax base definitions of the United States and the host country of the foreign subsidiary. The U.S. foreign tax credit is based on the average foreign tax rate of the subsidiary, where the average is calculated with respect to the U.S. definition of the tax base. Differences in tax base definitions may vary over time, e.g., if capital cost allowances differ, causing the average foreign tax rate as defined by the United States to vary. This 
variation in the average foreign tax rate causes the foreign tax credit allowed for a given dividend payment to vary over time as well. Such variations in the average foreign tax rate may be planned. For example, to the extent that the timing of deductions and credits is discretionary, a foreign subsidiary may shift them from years in which it is remitting income to years in which it is not remitting income, thereby maximizing the foreign tax credit. This device is known as the "rhythm method" in the tax planning jargon."

The second cause of variation in the repatriation tax is movement by the parent company between being in "excess credit," i.e., having more foreign tax credits available than are needed to offset potential U.S. tax liability on foreign source income, and being in "excess limitation," the opposite condition. Since the U.S. foreign tax credit operates, to some extent, on an overall basis, excess foreign tax credits generated from one source of foreign income can be used to offset potential U.S. tax on another source of foreign income that generates insufficient foreign tax credits. If the parent corporation is in excess credit, there is no additional U.S. tax cost to repatriating foreign income. If the parent is in excess limitation, then the U.S. tax cost of repatriating income from a subsidiary may be positive or negative, depending on the average foreign tax rate of the subsidiary.

Several recent theoretical contributions have incorporated a repatriation tax that may vary over time and that may be endogenous to the investment and financial decisions of subsidiaries and parent corporations. Hines (1989) shows that U.S. tax payments on foreign source income are affected by differences in the way the U.S. and host countries determine taxable income. 
In his model, the repatriation tax is a function of the ratio of U.S. defined income to foreign defined income. He points out that this ratio may vary over time and may be affected by investment decisions. As a result, investment incentives may be influenced by the repatriation tax. Leechor and Mintz (1993) make a similar argument. In their model, the repatriation tax is also endogenous and the Hartman result obtains only when host and home country tax bases, adjusted for inflation, are proportional to each other.

Altshuler and Fulghieri (1990) offer a model in which parent corporations may switch into and out of the excess credit position. This model shows that the Hartman result obtains only when the excess credit position is stationary. The insight here is that switching between credit states breaks down the equivalence between the impact of repatriation taxes on the opportunity cost of capital and on the retums to investment.

In one sense, none of these recent theoretical contributions has departed from the Hartman result: the level of the repatriation tax does not by itself affect the incentive to repatriate income rather than reinvest it. Instead, it is the variation over time in the level of the repatriation tax that affects the incentive to repatriate income, because this variation provides parent corporations with the opportunity to time remittances so that they occur in years when repatriation tax rates are relatively low. If these theoretical predictions are correct, then failure to distinguish between the effects of permanent and transitory variation in the tax price when estimating tax effects on repatriation of foreign income could lead to incorrect results. The 
effect of permanent variation in the tax price might be overstated, since the estimates would confound the effects of permanent and transitory variation in the tax price.

\section{The Tax Price of Dividend Repatriations}

In this section we specify a measure of the tax price of repatriating foreign income in the form of dividends and we briefly discuss the factors that may cause that tax price to vary over time. To understand how these tax prices are derived, some background information on the foreign tax credit is useful. The discussion here borrows heavily from Altshuler and Newlon (1993).

The foreign tax credit has two components. The first, called the direct credit, is a credit for foreign taxes paid directly on income as it is received by a U.S. taxpayer. Foreign taxes eligible for the direct credit include withholding taxes on remittances to the U.S. taxpayer such as dividends, interest, and royalties, and also income taxes on foreign branch operations. The second component, called the deemed-paid or indirect credit, is a credit for foreign income taxes paid on the income out of which a dividend distribution is made to the U.S. taxpayer. The deemed paid credit is generally a credit for foreign corporate income taxes.

The deemed paid credit for a dividend remittance from a foreign subsidiary is calculated by grossing up the dividend to reflect the foreign tax deemed paid on that dividend income. ${ }^{7}$ To illustrate, suppose subsidiary $i$ makes a dividend payment, $D_{i}$, to its parent corporation. The grossed up dividend is 


$$
D_{i}+T_{i} D_{i} /\left(Y_{i}-T_{i}\right)
$$

where $T_{i}$ denotes the total foreign income tax paid by subsidiary $i$ and $Y_{i}$ denotes the subsidiary's pre-tax income from the U.S. perspective, which is the subsidiary's book earnings and profits. Equation (1) can be rewritten as $D_{i} /\left(1-\tau_{i}\right)$, where $\tau_{j}$ represents the average subsidiary tax rate, $T_{V} / Y_{i}$, on foreign earnings from the U.S. perspective. The U.S. tax on the dividend before credits is $\tau D_{V} /\left(1-\tau_{i}\right)$, where $\tau$ denotes the U.S. rate of tax. The United States considers that creditable foreign tax was paid on the dividend in the amount of $\tau_{i} D_{i} /\left(1-\tau_{i}\right)$. The U.S. tax liability on the dividend payment after the deemed-paid credit is therefore $D_{i}\left(\tau-\tau_{i}\right) /\left(1-\tau_{i}\right)$.

The amount of foreign tax credit that can actually be used is limited, however, to the amount of U.S. tax payable on foreign income. Therefore, if the foreign tax rate, $T_{i}$, exceeds the U.S. tax rate, $\tau$, excess credits are created in the amount of $D_{i}\left(\tau_{i}-\tau\right) /\left(1-\tau_{i}\right)$. If the foreign tax rate is less than the U.S. tax rate, then a U.S. tax liability of $D_{i}\left(\tau-\tau_{i}\right) /\left(1-\tau_{i}\right)$ accrues and the remitted foreign income is said to be creating excess limitation.

As noted above, the limitation on the foreign tax credit operates to some extent on an overall basis. This means that excess credits accruing from one source of foreign income can often be used to offset U.S. tax (excess limitation) on foreign income from another source. This is called cross-crediting or averaging of foreign income. The ability to cross-credit means that the effect of repatriating foreign income from a particular source may be positive, negative or zero. $^{8}$ 


\section{The Derivation of Tax Prices}

We define the tax price of a dividend remittance as the additional global tax liability arising from an incremental dollar's worth of dividend repatriations. To derive the tax price we must take into account both the incremental U.S. and source country taxes on a dollar of dividends. The U.S. tax liability generated by dividend payments before the foreign tax credit equals $\tau D_{i} /\left(1-\tau_{j}\right)$. The foreign taxes creditable against U.S. tax liability are deemed-paid taxes plus withholding taxes, or

$$
\tau_{i} D_{i} /\left(1-\tau_{i}\right)+\omega_{i} D_{i}
$$

where $\omega_{i}$ denotes the withholding tax rate in the host country. If the parent is in excess credit, any U.S. tax liability on a dollar of dividends is offset by the foreign tax credit. If the parent is in excess limitation, the U.S. tax liability equals

$$
\left(\tau-\tau_{j}\right) D_{i} /\left(1-\tau_{i}\right)-\omega_{i} D_{i} \cdot
$$

To compute the global tax price of a dollar of dividends we add the source country effect to the U.S. tax effect. Under a classical corporate income tax system 9 the total source country tax liability on subsidiary i equals

$$
T_{i}=\tau_{i} Y_{i}+\omega_{i} D_{i}
$$

As a result, the only host country tax consequences of a dividend remittance are the associated withholding taxes. If the parent is in excess credits there is no U.S. tax consequence and therefore the global tax price is $\omega_{j}$. If the parent is in excess limitation the global tax price, $p$, is

$$
p=\left(\tau-\tau_{i}\right) /\left(1-\tau_{j}\right)
$$


The withholding tax has no net effect on global taxes because the extra withholding tax paid on the dividend remittance is offset by a reduction of U.S. tax of an equal amount. Due to crosscrediting, the global tax price may be negative and dividend payments may reduce the firm's global tax liability. ${ }^{10}$

Expression (5) shows that, if the parent corporation is in excess limitation, then the tax price of a dividend remittance is inversely related to the subsidiary's average tax rate, $\tau_{i}$. As noted previously, to the extent that these variations in $\tau_{i}$ are endogenous, e.g. because the timing of deductions and credits is elective, they can become a part of tax planning strategies for repatriating foreign source income. Even if a subsidiary's average tax rate is relatively constant, the tax price of remittances will fluctuate significantly when the subsidiary's parent switches credit position. Consider a subsidiary with an average tax rate above the U.S. corporate rate. When the parent is in excess limitation, the tax price of a dividend remittance is negative [( $\tau$ $\left.\left.\tau_{i}\right) /\left(1-\tau_{i}\right)<0\right]$. When the parent is in excess credit, the tax price equals the withholding tax rate. As a result, tax prices for some subsidiaries can be negative in some years and positive in others. These changes in tax prices may also be endogenous if parents can control their foreign tax credit positions through careful structuring of remittances from foreign subsidiaries. The next section presents an estimation strategy to separate the effect of these transitory components of tax prices from the effect of changes in the permanent component. 


\section{An Empirical Model of Dividend Repatriations}

Previous work by Hines and Hubbard (1990) and Altshuler and Newlon (1993). has estimated a simple empirical model of dividend repatriations. For subsidiaries paying a dividend the model takes the following basic form:

$$
d=a_{0}+a_{1} P+b r+X A+\epsilon,
$$

where $d$ is the dividend payout, expressed as the ratio of subsidiary dividends to assets, $P$ is the current tax price of dividend repatriation ${ }^{\prime \prime}, r$ is the after-tax rate of retum for the subsidiary, and $\mathrm{X}$ is a vector of characteristics of subsidiary and parent. Equation (6) is not derived explicitly from the firm's optimization problem, but can be considered a reduced form suitable for testing the general implications of theoretical models such as Hartman's. It is similar to the empirical models used to explain dividend payments in a purely domestic context.

In these previous papers, $P$ was expected to have a negative coefficient since higher tax prices were expected to reduce the attractiveness of repatriation. The after-tax rate of retum, $r$, may have an ambiguous effect on the dividend payout. On the one hand, if dividend payments are a residual, then higher earnings, which would increase the measured rate of retum, could be expected ceteris paribus to increase the dividend payout. On the other hand, a higher after-tax rate of return would increase desired investment, having the effect of increasing retained earnings and reducing the dividend payout. Other relevant variables are included in $\mathrm{X}$, the most important of which is perhaps the age of the subsidiary. Some theoretical literature (such as Newlon (1987) and Sinn (1990)) suggests that older subsidiaries should have higher dividend payout ratios. This prediction is a direct consequence of the value of deferral when 
there is a repatriation tax, i.e., if there is deferral, then dividend payouts will on average be an increasing function of age, other things constant.

As noted already, by using the current tax price, $P$, the above model may confound the potentially different effects of permanent and transitory components of the tax price. It is beyond the scope of this paper to derive a theoretical model that explicitly incorporates intertemporal variation in repatriation tax prices. Instead, we use a reduced form empirical model to test the general implications that could be expected from any such model. In particular, a transitory decrease (increase) in the tax price reduces the current tax price relative to future tax prices, and thus enables the firm to increase the value of its foreign source income by accelerating (delaying) dividend repatriations. But a permanent change in the tax price does not change the relative prices of current and future repatriation. Therefore, one would expect dividend repatriations to be affected more by transitory than by permanent changes in tax prices. And Hartman's (1985) work would indicate that permanent changes in tax prices should have no effect at all on dividend repatriations.

Based on these considerations, our empirical model generalizes equation (6) to allow for differences in transitory and permanent tax price effects:

$$
d=a_{0}+a_{1}(P-P)+a_{2} P^{\infty}+b r+X A+\epsilon,
$$

where $\mathrm{P}^{*}$ is the permanent component of the tax price and hence (P-P) is the transitory component. We estimate this in a slightly different form:

$$
d=a_{0}+a_{1} P+\left(a_{2}-a_{1}\right) P^{*}+b r+X A+\epsilon
$$


One difficulty in estimating equation (8) is that the permanent component of the tax price, $P^{*}$, is unobservable. To capture the effect of $P^{*}$ we use an instrumental variables approach in which we instrument the tax price on a variable, $P^{i}$, that we expect to be correlated with the permanent component of the tax price but uncorrelated with its transitory component. This essentially involves replacing $\mathbf{P}^{*}$ in equation (8) with its predicted value,

$$
\hat{\mathbf{P}}^{*}=\hat{\mathrm{b}}_{0}+\hat{\mathrm{b}}_{1} \mathrm{P}^{\mathrm{i}}+\hat{\mathrm{b}}_{2} \mathrm{r}+\mathrm{X} \hat{\mathrm{B}} \text {, }
$$

where the coefficients are derived from the regression

$$
P^{*}=b_{0}+b_{1} P^{i}+b_{2} r+X B+\xi \text {. }
$$

We experiment with two alternative instruments for the permanent component of the tax price, the country average tax price and the country statutory withholding tax rate. These instruments reflect cross-country variation in taxes that should also be reflected in the permanent component of the tax price but not in the purely transitory component.

For estimation of (8), we use a Tobit procedure because dividend payments are censored at zero. On the surface, this may appear unnecessary since actual dividend payments are, by definition, non-negative. However, the desired level of dividend payments could be negative. This result would obtain if, as suggested by the theoretical work in this area, foreign retained earnings were the preferred source of finance for foreign investment but foreign investment exceeded foreign earnings. Our use of a Tobit procedure implicitly assumes that we have modelled desired dividends, but only observe actual dividends. 


\section{The Data}

Our data set contains information from three sets of tax and information forms filed by a large sample of non-financial U.S. multinational corporations. Subsidiary data are obtained from information returns, called 5471 forms, filed for each foreign subsidiary of a U.S. taxpayer. The form 5471 includes balance sheet and income statement variables along with detailed information on remittances to U.S. parent corporations. For the purposes of this study, we needed to append information on the taxable income and foreign tax credit position of parent corporations to the subsidiary specific data from the form $5471 \mathrm{~s}$. We obtained income data from corporate income tax returns filed by the U.S. parent corporations. We calculated foreign tax credit positions using data from the forms filed in support of foreign tax credit claims. Detailed

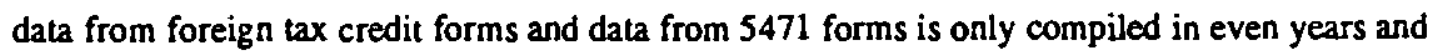
were available to us only for the years $1980,1982,1984$, and 1986.

Calculating subsidiary-specific tax prices for dividend remittances for each sample year also requires knowledge of the host country withholding tax rates; the appropriate foreign corporate tax rates, and details of host country tax systems. To develop a list of country specific withholding tax rates for each sample year, we used the Price Waterhouse guides and tax treaties. These guides also provided the appropriate statutory tax rates for the countries in our sample with non-classical (for example, split rate and imputation) corporate tax systems. Finally, in each year of the sample we used the subsidiary's average foreign tax rate to measure the corporate tax rate $\tau_{i}$ at which dividends are grossed-up and foreign tax credits are calculated. 
To calculate this rate we divided foreign tax payments by before-tax eamings and profits, both obtained from the 5471 form data.

In some situations, calculating average tax rates in this manner may lead to an unsatisfactory approximation of $\tau_{i}$. In particular, problems arise when subsidiaries report negative earnings and profits, receive tax refunds from host countries, repatriate dividends in excess of current earnings and profits, and receive dividends from subsidiaries of their own. Where feasible, adjustments were made in these cases to arrive at a more satisfactory measure of $\pi_{\mathrm{i}}{ }^{12}$ Various screens were also applied to the data to eliminate observations for which the data were suspect. After these deductions the total number of observations in the sample was 22,906 .

Some of the estimation required linking subsidiaries in two consecutive sample years to form a panel. This was done largely through an algorithm that matched subsidiaries based on their U.S. parent corporation, company name, date of incorporation and country of residence. Many subsidiaries could not be matched on this basis and they therefore could not be included in the panel. The total number of observations in the panel was 7,118 .

Table 1 presents for each country represented in the sample the mean tax price, the standard deviation of the tax price, the statutory withholding tax rate and the mean dividend asset ratio for the subsidiaries located in that country for 1984 . This table provides information that may be valuable in evaluating the usefulness of country mean tax prices and statutory 
withholding tax rates as instruments for the permanent component of the tax price. First note that there is substantial variation in country mean tax prices and in statutory withholding tax rates. Mean country tax prices range from -0.21 for Germany to 0.38 for Greece. Statutory withholding tax rates range from zero for a number of tax haven countries to 55 percent for Mexico. This degree of variation across countries means that these variables may be useful instruments, since the cross-country variation is presumably correlated with variation in the permanent component of the tax price.

Note also that within each country the standard deviation of the tax price is relatively large, in no case less than 0.14 . This demonstrates that there is a substantial portion of variation in tax prices not explained by differences in country statutory dividend withholding and corporate income tax rates. Finally, note that no clear relationship between country mean dividend payout ratios and country mean tax prices or statutory withholding rates emerges from inspection of Table l. This presages the results presented in the next section.

\section{Results}

Table 2 presents the estimation results. Column 1 of the table presents the results of estimating the simple dividend model presented in equation (6) that incorporates only the current tax price of repatriation. These estimates use the full sample of 22,906 observations. They are presented to check that the results with our sample are essentially the same as found by Hines and Hubbard and Altshuler and Newlon. 
The results presented in column (1) are indeed similar to those found in previous work. The coefficient on the tax price is negative and statistically significant and of similar magnitude to the estimates in previous papers. To gauge the economic significance of this coefficient, note that it implies that a reduction in tax price of one standard deviation (0.34) implies an increase in the overall dividend payout ratio (including those that pay dividends and those that do not) of about 0.004 , which is equal to about 11 percent of the mean dividend payout ratio of 0.036 . Thus, moving the tax price from one standard deviation above the mean to one standard deviation below the mean implies an increase in the dividend payout ratio equal to about 22 percent of the mean dividend payout ratio.

The coefficient on the after-tax rate of return is positive, significant and less than one. This is plausible, since it implies that an increase in eamings increases dividend payments. Because it is significantly less than 1 , the coefficient also suggests that an increase in the aftertax rate of retum increases retained earnings. Also as expected, the coefficient on subsidiary age is positive and significant.

Column (2) and the remaining columns of the table present the results of estimating the model in equation (8) that distinguishes between permanent and transitory tax price effects. To interpret the tax price coefficient estimates in these columns recall that in equation (8) the effect of the transitory component of the tax price is captured by the coefficient on the current tax price, while the coefficient on the permanent tax price equals the difference between the permanent and transitory tax price effects. Thus, the coefficient estimates in the first row of the 
table represent transitory tax price effects, the second row coefficient estimates represent the difference between the permanent and transitory tax price effects, and the coefficient estimates in the third row, which are sums of the coefficients in the first two rows, represent permanent tax price effects.

Column (2) of Table 2 shows estimates, using the full sample, of the basic model in which the country mean tax price is used as an instrument for the permanent component of the tax price. The estimated effect of the transitory component of the tax price (in the first row) is negative and statistically significant. Furthermore, it is larger in absolute magnitude than the estimated effect from the model excluding the permanent tax price effect. ${ }^{13}$ This result implies that transitory variation in the tax price has a large effect on the incentive to repatriate income.

The estimated difference between the permanent and transitory tax price effects presented in the second row of column (2) is positive and statistically significant. This implies that the permanent component of the tax price is not only significantly different from the transitory tax price effect, but, since the coefficient is positive, cannot have as large a negative impact on dividend repatriations. In fact, the estimated permanent tax price effect presented in the third row is not significantly different from zero. These results provide support for the hypothesis that the dividend repatriation incentive is affected by transitory but not permanent changes in the tax price of repatriation, a result that is consistent with Hartman's analysis. 
One potential problem with the results from the basic model in column (2) arises because the tax incentive to retain eamings abroad should depend on the expected foreign after-tax rate of retum, but we use the actual rate for the current year in our estimates. This may bias the coefficient on the after-tax rate of retum toward zero. More importantly, the difference between the current and expected after-tax rates of return will be part of the error term. Consequently, the current tax price and the country mean tax price will both be correlated with the error term because both depend on current foreign taxes and income. This may bias the coefficients on the current and permanent tax prices.

To explore whether this is a significant problem we used the two year lead after-tax rate of return as an instrument for the expected after-tax rate of return. The motivation for this approach is that, under rational expectations, the difference between the future actual and expected after-tax rates of retum (the forecast error) should be independent of the current aftertax rate of retum, which reflects only current information.

This approach reduces the sample size in two ways. First, use of the two-year lead means that only the first three years of the data can be used. Second, only observations for which matches could be found in the following year of the sample could be used. As mentioned above, these restrictions reduced the sample size to 7,118 .

There is some risk that the selection of subsidiaries dropped from the sample by these requirements was not random. For example, current income repatriation might depend on 
whether there are plans to sell a subsidiary in the future, and subsidiaries sold within two years would be excluded from the sample. Subsidiaries that are being shut down might also be more or less likely to pay dividends, and a subsidiary shut down within two years would be excluded from the sample. If for these or other reasons the selection was significantly non-random, selection bias might be induced.

To investigate whether there is any potential selection bias, column (3) of the table presents the results of estimating the basic model of column (2) using the restricted sample. Note that a higher percentage of the subsidiaries in the restricted sample pay dividends to their U.S. parent corporation. This is consistent, for example, with dividend payments being lower before a subsidiary is sold or shut down. But note that based on Hausman tests on the individual coefficients of interest the regression results do not differ significantly from those obtained using the full sample. Thus, there are no signs of selection bias in the restricted sample.

Column (4) of the table presents the results of the regression using the two-year lead after-tax rate of return as an instrument for the expected after-tax rate of return. The coefficient on the after-tax rate of retum increases, and the difference is significant based on a Hausman test. This coefficient implies that a higher expected after-tax rate of return is associated with greater retention of earnings, but not by as much as measured in the previous regressions. The tax price coefficients are not significantly different from those in column (2). ${ }^{14}$ These results therefore provide no evidence that the permanent tax price coefficients are biased by using the current instead of the expected future foreign after-tax rate of return. 
A second potential problem arises because even afler controlling for differences in country average tax prices and the other regression variables using the instrumental variables approach the current tax price may still be correlated with the permanent tax price. This is because the permanent tax price may depend not only on cross-country differences in taxes, but also on the portfolio of subsidiaries held by the U.S. parent corporation, on the parent's U.S. operations, and on expectations about the future. This problem also could bias the tax price coefficients. It would tend to bias the transitory tax price coefficient toward the permanent tax price coefficient and bias the permanent tax price coefficient (i.e., the estimated difference between the permanent and transitory tax price effects) toward zero.

To determine whether this is a serious problem we estimated the model using the change in tax price between the current year and the two-year lead as an instrument for the transitory tax price. This approach was adopted because the change in the tax price is likely to be less correlated than the current tax price with the permanent tax price. The results of this estimation are presented in column (5) of the table. There is no significant change in any of the coefficients, they are simply estimated with somewhat less precision. Thus, there is no evidence that the tax price coefficients are biased from a correlation between the current and permanent tax prices.

A third problem may exist because much of the variation in the country mean tax price comes from variations in effective corporate tax rates across countries, but variations in foreign effective corporate tax rates may also affect foreign after-tax rates of return. As a result it may 
be difficult to separately identify the effects of variations in foreign effective tax rates as they affect repatriation through their effect on the tax price of repatriation and as they affect repatriation through their effects on the foreign after-tax rate of retum. For example, a higher foreign corporate tax rate will decrease the tax price of repatriation for the subsidiary of a U.S. corporation that is in excess limitation, but it will also, ceteris paribus, decrease the foreign after-tax rate of retum, thereby decreasing the incentive to defer repatriation of foreign income. Although the models we estimate attempt to avoid this problem by controlling separately for the foreign after-tax rate of retum, the measure we use is imperfect and hence there is some possibility of misspecification biasing the tax price results.

Our first approach to testing whether this is a significant problem is to use the country statutory dividend withholding tax rate in place of the country mean tax price as an instrument for the permanent component of the tax price. The statutory withholding tax rate is related to the tax price, but has no direct relation to the corporate tax rate. Column (6) of the table presents the results of this estimation, using the full sample again. Note that the permanent tax price coefficient changes very little from the basic model estimate in column (2). The difference is not statistically significant based on a Hausman test. This provides some evidence that there is no serious misspecification problem.

The approach used to generate the results presented in column (6) may not provide a conclusive fix for the potential problem, because country statutory withholding tax rates are correlated with country corporate tax rates. To address this additional possible difficulty we 
remove the correlation from the withholding rate instrument. To do this we regress the withholding rate on the country mean average corporate tax rate and the country statutory tax rate and use the residual from this regression as an instrument for the permanent component of the tax price. In other words, we use as an instrument the part of the withholding tax rate that is orthogonal to the country mean tax rate and the statutory corporate tax rate. The results of this procedure are presented in column ( 7$)$ of the table. Here again the coefficient on the permanent component of the tax price is not significantly different, based on a Hausman test, from the coefficient obtained in the estimates of the basic model presented in column (2).

\section{Conclusion}

The tax price effects on dividend repatriations found in previous studies using the simple model of dividend repatriations apparently measure largely the effect of the timing of dividend repatriations to take advantage of intertemporal variation in tax prices. These timing opportunities may arise either endogenously, through tax planning that affects both tax prices and dividend payments, or through exogenously caused variations in tax prices. Therefore, although repatriation taxes seem to affect dividend repatriation behavior, this is apparently only because tax prices vary over time. This result is consistent with the prediction of Hartman's model.

The results presented here should not be construed to imply that the "permanent" levels of host and home country taxation do not affect dividend repatriation by foreign subsidiaries. Host and home country corporate taxation will of course affect the earnings reinvestment 
decision, and hence the dividend repatriation decision, through their impacts on host and home country after-tax rates of retum. The evidence from our estimates merely implies that host and home country taxation do not affect repatriation through the permanent component of the repatriation tax.

Our results may have policy implications. The most obvious implications relate to policies on dividend withholding tax rates. For example, many capital-importing countries consider lowering withholding taxes, either unilaterally or in the context of bilateral tax treaty negotiations, to try to attract new equity investment. But some countries may be inhibited by the fear that such a measure would lead to increased flight of the accumulated multinational equity "trapped" by existing high withholding taxes. Our results suggest that, as long as the reduction in the withholding tax rate is viewed as permanent, such fears are unfounded. Permanent changes in dividend withholding tax rates appear likely mainly to attract new equity investment and not to encourage repatriation of equity accumulated from past earnings. ${ }^{\text {is }}$.

To the extent that these results support the Hartman model, they have implications regarding the incentive effects of the credit and deferral system that the United States uses to tax most foreign income of U.S. multinationals. In particular, if the repatriation tax is irrelevant for the dividend repatriation decision, then, at least as regards retained earnings, the incentives for foreign investment are the same as they would be under a system that exempts foreign income from taxation. 


\section{REFERENCES}

Altshuler, Rosanne and Paolo Fulghieri. 1990. "Incentive Effects of Foreign Tax Credits on Multinationals," Columbia University Working Paper $\$ 478$. and T. Scott Newlon. 1993. "The Effects of U.S. Tax Policy on the Income Repatriation Patterns of U.S. Multinational Corporations," in A. Giovannini, G. Hubbard, and J. Slemrod, Studies in International Taxation. Chicago: University of Chicago Press, pp. 77-115.

Auerbach, Alan J. 1979. "Wealth Maximization and the Cost of Capital," Quarterly Journal of Economics, 93.

Bradford, David. 1981. "The Incidence and Allocation Effects of a Tax on Corporate Distributions," Joumal of Public Economics, XV.

Burman, Leonard and William Randolph. 1993. "Distinguishing Permanent from Transitory Effects of Capital Gains Tax Changes: New Evidence from Micro Data," forthcoming, American Economic Review.

Goodspeed, Timothy and Daniel J. Frisch. 1989. 'U.S. Tax Policy and the Overseas Activities of U.S. Multinational Corporations: A Quantitative Assessment," manuscript, U.S. Treasury Office of Tax Analysis.

Hartman, David. 1985. "Tax Policy and Foreign Direct Investment," Journal of Public Economics, 26.

Hines, James R. 1989. "Credit and Deferral as International Investment Incentives," manuscript, Princeton University, August. 
and R. Glenn Hubbard. 1990. "Coming Home to America: Dividend Repatriations by U.S. Multinationals," in A. Razin and J. Slemrod, eds., Taxation in the Global Economy. Chicago: University of Chicago Press, pp. 161-198.

King, Mervyn. 1977. Public Policy and the Corporation. London: Chapman and Hall.

Leechor, Chad and Jack Mintz. 1993. "On the Taxation of Multinational Corporate Investment when the Deferral Method is used by the Capital Exporting Country," Joumal of Public Economics, 51.

Mutti, John. 1981. "Tax Incentives and Repatriation Decisions of U.S. Multinational Corporations," National Tax Joumal, 34.

Newlon, T. Scott. 1987. "Tax Policy and the Multinational Firm's Financial Policy and Investment Decisions," Ph.D. Dissertation, Princeton University.

Price Waterhouse. 1980, 1982, 1984, and 1986. Corporate Taxes: A Worldwide Summary. New York.

Sinn, Hans Werner. 1990. "Taxation and the Birth of Foreign Subsidiaries," NBER Working Paper \#3519. 


\section{ENDNOTES}

1. See King (1977), Auerbach (1979) and Bradford (1981).

2. The term "normal" is used here to imply that there is some permanent, or long-run average, repatriation tax cost that the multinational faces. By "normal" tax cost we reaily mean expected future tax cost.

3. The Subpart F provisions of the tax code provide for accrual basis taxation on certain foreign income.

4. Note that this result does not imply that home and host country taxes have no effect on the repatriation decision. They do have an impact due to their effect on home and host country after-tax rates of retum, but not through the tax on repatriation.

5. The rhythm method was a more useful tax planning device for U.S. multinationals prior to the Tax Reform Act of 1986, when the foreign tax credit was calculated year by year. The 1986 Act switched to a system in which the foreign tax credit is calculated based on the pool of previously unremitted foreign earnings and uncredited taxes, and, therefore, shifting the year in which tax credits and deductions are taken has much less effect on the foreign tax rate for U.S. foreign tax credit purposes.

6. Although we focus on dividend payments, income may be remitted to parent companies in the form of interest, rents and royalty payments. Previous work by Altshuler and Newlon (1993) suggests that dividend payments are the most important channel for income remittances, making up over 60 percent of the total foreign income derived by U.S. parents from their foreign subsidiaries in 1986. 
7. As mentioned above, for tax years beginning in 1987, the amount of foreign tax credit associated with a dividend payment is based on the accumulated value of eamings and profits. Although this changes the gross-up formula in the text, it is not relevant for our analysis since our data is taken from years prior to 1986.

8. Congress has restricted cross-crediting by creating baskets of different types of foreign income to each of which a separate foreign tax credit limitation applies. Before the 1986 Act, the period which our study covers, there were five separate baskets: (1) one for investment interest income, (2) one for Domestic International Sales Corporation dividend income, (3) one for the foreign trade income of a Foreign Sales Corporation, (4) another for distributions from a Foreign Sales Corporation, and (5) one for all other foreign source income, which we will call general limitation income. The 1986 Act decreased the potential for cross-crediting further by increasing the number of separate limitation baskets to nine.

9. For simplicity we focus our discussion in this section on the derivation of the tax price of a dividend remittance from a foreign subsidiary operating in a country that uses a classical corporate tax system. In our empirical work we also take details of host country tax systems into account since our sample includes subsidiaries that operate in countries with split-rate and imputation systems. The derivation of the tax prices for these types of tax systems are discussed in detail in Altshuler and Newlon (1993).

10. We neglect here the cases in which the parent corporation has tax losses, since, as in earlier papers by Hines and Hubbard (1990) and Altshuler and Newlon (1993), we include in our sample only those U.S. corporations with positive worldwide taxable income. They are excluded here for simplicity's sake, since the carryover rules for tax losses and foreign tax 
credits can interact in ways that may complicate the incentives for income repatriation of these firms.

11. Altshuler and Newlon (1993) also use a measure of the "expected" tax price that attempts to take into account the fact that excess foreign tax credits can be carried back to several prior years or forward to several future years to offset taxes in those years.

12. See Altshuler and Newlon (1993) for a description of the methodology.

13. A Hausman test shows that this difference is statistically significant.

14. The coefficient on the current tax price is just barely significantly different $(T=2.0)$, but the significance is probably overstated since we have not adjusted the standard errors yet to account for instrumental variables estimation.

15. If a reduction in withholding tax rates is perceived by multinational investors as a signal of more favorable and stable policies towards multinational investment it may in fact increase reinvestment of eamings. 
Table 1: Country Averages, 1984

\begin{tabular}{|c|c|c|c|c|}
\hline Country & $\begin{array}{c}\text { Mean, } \\
\text { dividends } \\
\text { / assets }\end{array}$ & $\begin{array}{c}\text { Mean, } \\
\text { tax price }\end{array}$ & $\begin{array}{c}\text { Stand. } \\
\text { dev., } \\
\text { tax price }\end{array}$ & $\begin{array}{l}\text { With- } \\
\text { holding } \\
\text { tax rate }\end{array}$ \\
\hline W. Germany" & $3.9 \%$ & -0.21 & 0.38 & $15 \%$ \\
\hline Japan & $2.7 \%$ & -0.15 & 0.48 & 10 \\
\hline Norway" & $1.6 \%$ & -0.11 & 0.19 & 15 \\
\hline U. Kingdom ${ }^{*}$ & $2.2 \%$ & -0.10 & 0.38 & 5 \\
\hline Austria & $4.2 \%$ & 0.02 & 0.41 & 6 \\
\hline Sweden & $0.7 \%$ & 0.03 & 0.34 & 5 \\
\hline France & $2.2 \%$ & 0.03 & 0.34 & 5 \\
\hline Finland & $4.2 \%$ & 0.03 & 0.47 & 5 \\
\hline Italy & $2.4 \%$ & 0.07 & 0.26 & 6 \\
\hline Denmark & $1.8 \%$ & 0.07 & 0.22 & 6 \\
\hline Luxembourg & $1.0 \%$ & 0.08 & 0.49 & 6 \\
\hline Malaysia & $2.6 \%$ & 0.08 & 0.29 & 0 \\
\hline Peru & $3.4 \%$ & 0.08 & 0.79 & 40 \\
\hline Canada & $3.7 \%$ & 0.08 & 0.26 & 5 \\
\hline Belgium & $2.3 \%$ & 0.13 & 0.35 & 15 \\
\hline Singapore & $5.1 \%$ & 0.13 & 0.29 & 0 \\
\hline Costa Rica & $4.8 \%$ & 0.13 & 0.37 & 15 \\
\hline Netherlands & $2.7 \%$ & 0.14 & 0.20 & 5 \\
\hline New Zealand & $2.3 \%$ & 0.14 & 0.22 & 15 \\
\hline Colombia & $4.9 \%$ & 0.15 & 0.23 & 20 \\
\hline Australia & $2.2 \%$ & 0.16 & 0.24 & 15 \\
\hline SouthAfrica & $3.9 \%$ & 0.16 & 0.20 & 15 \\
\hline Guatemala & $3.9 \%$ & 0.17 & 0.27 & 13 \\
\hline Thailand & $4.7 \%$ & 0.18 & 0.18 & 20 \\
\hline Brazil & $4.0 \%$ & 0.19 & 0.51 & 25 \\
\hline Neth. Antilles & $1.0 \%$ & 0.19 & 0.23 & 0 \\
\hline Bahamas & $3.4 \%$ & 0.19 & 0.25 & 0 \\
\hline Ireland & $3.6 \%$ & 0.20 & 0.25 & 0 \\
\hline Portugal & $0.9 \%$ & 0.20 & 0.22 & 25 \\
\hline HongKong & $4.9 \%$ & 0.21 & 0.21 & 0 \\
\hline Philippines & $1.7 \%$ & 0.22 & 0.14 & 20 \\
\hline Bermuda & $3.5 \%$ & 0.23 & 0.23 & 0 \\
\hline Spain & $1.9 \%$ & 0.23 & 0.14 & 18 \\
\hline Venezuela & $2.0 \%$ & 0.24 & 0.18 & 20 \\
\hline Cayman Is. & $2.8 \%$ & 0.24 & 0.23 & $\mathbf{0}$ \\
\hline Mexico & $2.6 \%$ & 0.25 & 0.43 & 55 \\
\hline Chile & $5.1 \%$ & 0.25 & 0.20 & 30 \\
\hline Argentina & $2.8 \%$ & 0.25 & 0.29 & 18 \\
\hline Panama & $4.6 \%$ & 0.26 & 0.23 & 10 \\
\hline Taiwan & $3.4 \%$ & 0.27 & 0.35 & 35 \\
\hline Liberia & $1.2 \%$ & 0.28 & 0.15 & 15 \\
\hline Greece" & $2.0 \%$ & 0.38 & 0.28 & 47 \\
\hline$\overline{\text { All subsidiaries }}$ & $2.9 \%$ & 0.08 & 0.34 & $\overline{11}$ \\
\hline
\end{tabular}

* Non-classical countries 
Table 2: Tobit Model Estimation Results

(dependent variable: subsidiary dividends over assets; standard errors in parentheses)

\begin{tabular}{|c|c|c|c|c|c|c|c|}
\hline \multirow{2}{*}{$\begin{array}{l}\text { RHS variables, } \\
\text { estimation detajls }\end{array}$} & \multicolumn{2}{|c|}{ Full sample } & \multicolumn{3}{|c|}{$\begin{array}{l}\text { Partial sample matched } \\
\text { with 2-year leads }\end{array}$} & \multicolumn{2}{|c|}{ Full sample } \\
\hline & (1) & (2) & (3) & (4) & (5) & $(6)$ & $(7)$ \\
\hline $\begin{array}{l}\text { Current (global) } \\
\text { tax price (tp) }\end{array}$ & $\begin{array}{l}-0.046 \\
(.0057)\end{array}$ & $\begin{array}{l}-0.059 \\
(.0062)\end{array}$ & $\begin{array}{l}-0.066 \\
(.0109)\end{array}$ & $\begin{array}{l}-0.078 \\
(.0114)\end{array}$ & $\begin{array}{r}-0.070 \\
(.020)\end{array}$ & $\begin{array}{l}-0.047 \\
(.0057)\end{array}$ & $\begin{array}{l}-0.049 \\
(.0058)\end{array}$ \\
\hline $\begin{array}{l}\text { Permanent } \\
\text { tax price }\end{array}$ & $\cdots$ & $\begin{array}{r}0.087 \\
(.016)\end{array}$ & $\begin{array}{r}0.092 \\
(.0263)\end{array}$ & $\begin{array}{r}0.089 \\
(.0265)\end{array}$ & $\begin{array}{r}0.080 \\
(.031)\end{array}$ & $\begin{array}{r}0.080 \\
(.076)\end{array}$ & $\begin{array}{r}0.13 \\
(.038)\end{array}$ \\
\hline $\begin{array}{l}\text { Sum of tax price } \\
\text { coeffjcients }^{b}\end{array}$ & $\cdots$ & $\begin{array}{r}0.027 \\
(.015)\end{array}$ & $\begin{array}{r}0.027 \\
(.024)\end{array}$ & $\begin{array}{r}0.010 \\
(.024)\end{array}$ & $\begin{array}{r}0.010 \\
(.024)\end{array}$ & $\begin{array}{r}0.033 \\
(.076)\end{array}$ & $\begin{array}{r}0.078 \\
(.038)\end{array}$ \\
\hline $\begin{array}{l}\text { Subsidiary } \\
\text { earnings / assets }\end{array}$ & $\begin{array}{r}0.58 \\
(.016)\end{array}$ & $\begin{array}{r}0.55 \\
(.016)\end{array}$ & $\begin{array}{r}0.49 \\
(.027)\end{array}$ & $\begin{array}{r}0.80 \\
(.055)\end{array}$ & $\begin{array}{r}0.80 \\
(.055)\end{array}$ & $\begin{array}{r}0.55 \\
(.032)\end{array}$ & $\begin{array}{r}0.53 \\
(.021)\end{array}$ \\
\hline $\begin{array}{r}\text { Subsidiary } \\
\text { age / } 100\end{array}$ & $\begin{array}{r}0.37 \\
(.017)\end{array}$ & $\begin{array}{r}0.38 \\
(.017)\end{array}$ & $\begin{array}{r}0.33 \\
(.028)\end{array}$ & $\begin{array}{r}0.33 \\
(.028)\end{array}$ & $\begin{array}{r}0.33 \\
(.028)\end{array}$ & $\begin{array}{r}0.38 \\
(.022)\end{array}$ & $\begin{array}{r}0.39 \\
(.018)\end{array}$ \\
\hline $\begin{array}{l}\text { Permanent IV } \\
\text { (1) country mean tp } \\
\text { (2) withholding rate }\end{array}$ & & $\mathbf{x}$ & $\mathbf{x}$ & $\mathbf{x}$ & $\mathbf{x}$ & $\mathbf{x}$ & $x^{\mathfrak{c}}$ \\
\hline$\frac{\text { Income IV }}{2-\text { year forward }}$ & & & & $\mathbf{x}$ & $x$ & & \\
\hline$\frac{\text { Transitory IV }}{2-\text { year change in tp }}$ & & & & & $\mathbf{x}$ & & \\
\hline Intercept (1980) & $\begin{array}{r}-0.29 \\
(.0059)\end{array}$ & $\begin{array}{r}-0.29 \\
(.0060)\end{array}$ & $\begin{array}{l}-0.24 \\
(.0093)\end{array}$ & $\begin{array}{l}-0.28 \\
(.012)\end{array}$ & $\begin{array}{l}-0.28 \\
(.012)\end{array}$ & $\begin{array}{l}-0.26 \\
(.0051)\end{array}$ & $\begin{array}{r}-0.29 \\
(.0064)\end{array}$ \\
\hline 1982 Dummy & $\begin{array}{r}0.026 \\
(.0051)\end{array}$ & $\begin{array}{r}0.026 \\
(.0051)\end{array}$ & $\begin{array}{r}0.038 \\
(.0071)\end{array}$ & $\begin{array}{r}0.039 \\
(.0073)\end{array}$ & $\begin{array}{r}0.039 \\
(.0073)\end{array}$ & $\begin{array}{r}0.030 \\
(.0054)\end{array}$ & $\begin{array}{r}0.026 \\
(.0051)\end{array}$ \\
\hline 1984 Dummy & $\begin{array}{l}-0.029 \\
(.0053)\end{array}$ & $\begin{array}{l}-0.030 \\
(.0053)\end{array}$ & $\begin{array}{r}-0.0037 \\
(.0085)\end{array}$ & $\begin{array}{r}0.00075 \\
(.0088)\end{array}$ & $\begin{array}{r}0.00098 \\
(.0088)\end{array}$ & $\begin{array}{l}-0.030 \\
(.0053)\end{array}$ & $\begin{array}{l}-0.031 \\
(.0054)\end{array}$ \\
\hline 1986 Dummy & $\begin{array}{l}-0.012 \\
(.0065)\end{array}$ & $\begin{array}{l}-0.012 \\
(.0065)\end{array}$ & $\ldots$ & $\cdots$ & $\cdots$ & $\begin{array}{l}-0.012 \\
(.0066)\end{array}$ & $\begin{array}{l}-0.013 \\
(.0066)\end{array}$ \\
\hline Observations & 22,906 & 22,906 & 7,118 & 7,118 & 7,118 & 22,906 & 22,906 \\
\hline Paying dividends & $28 \%$ & $28 \%$ & $37 \%$ & $37 \%$ & $37 \%$ & $28 \%$ & $28 \%$ \\
\hline
\end{tabular}

Notes:

a Measures the difference between effects of changes in permanent and transilory tax prices. (transilory tax price $=$ cutrent tax price - permanent tax price)

b Measures the effect of permanent tax price changes, holding the transitory tax price constant.

c Uses part of withholding rate orthogonal to the foreign statulory and country mean average tax rates. 